Phenological characterization of grapevine cultivars used in winemaking in Rio Grande do Norte, Brazil

\title{
Caracterização fenológica de cultivares de videira utilizada na fabricação de vinho no Rio Grande do Norte, Brasil
}

\author{
Wagner César de Farias ${ }^{1}$; Luana Mendes de Oliveira ${ }^{2}$; Wilma Freitas Celedônio ${ }^{3}$; Django de Jesus Dantas ${ }^{4}$; Vander \\ Mendonça ${ }^{5}$ : Aline Carla de Medeiros ${ }^{6}$
}

\begin{abstract}
The vegetative cycle of the vine (Vitis vinifera) in temperate regions extends from budding to leaf fall, while the same cycle in tropical regions differs by the non-existence of falling leaves and vegetative dormancy. In this case, the water deficit induces the dormancy after fruits harvest. We aimed to describe the phenological behavior of five grapevine cultivars. We carried out an experiment between May and September 2015, in the municipality of Martins, Rio Grande do Norte, Brazil, with the following five cultivars of European vines: Malbec, Merlot Noir, Chardonnay, Cabernet Sauvignon, and Syrah. The experimental design was a randomized block with four replications, each plot with five plants. Phenological observations were carried out during the entire cycle, from pruning to harvesting. The cultivar Syrah showed a lower pruning cycle with 98 days, followed by cultivars Malbec, Merlot Noir, Cabernet Sauvignon, and Chardonnay which showed cycles of 101, 103 , 105 and 110 days respectively.
\end{abstract}

Key words: Fruticulture; Vitis vinifera; Phenology.

Resumo: O ciclo vegetativo da videira em regiões de clima temperado é o período entre a brotação e a queda das folhas, enquanto o mesmo ciclo em regiões tropicais se diferencia pela não existência de queda das folhas e o repouso vegetativo, nesse caso induzido por déficit hídrico após a colheita dos frutos. O objetivo deste trabalho foi caracterizar o comportamento fenológico das cinco cultivares de videira. O experimento foi realizado entre maio e setembro de 2015, no município de Martins, localizado na região Oeste do Rio Grande do Norte, sendo constituído por cinco tratamentos representados por cultivares de videiras europeias (Vitis vinífera). As cultivares foram as seguintes: Malbec, Merlot Noir, Chardonnay, Cabernet Sauvignon e Syrah. O delineamento experimental utilizado foi em blocos casualizados com quatro repetições, e parcelas constituídas por 5 plantas. As observações fenológicas foram realizadas durante todo o ciclo, a partir da poda até a colheita. A cultivar Syrah apresentou menor ciclo poda-colheita com 98 dias, seguida das cultivares Malbec, Merlot Noir, Cabernet Sauvignon e Chardonnay apresentaram 101, 103, 105 e 110 dias respectivamente.

Palavras-chave: Fruticultura; Vitis vinífera; Fenologia.

\footnotetext{
*Autor para correspondência

Recebido para publicação em 10/04/2016; aprovado em 20/06/2017

${ }^{1}$ Eng. Agro. doutorando do programa de pós-graduação em Fitotecnia, Universidade Federal Rural do Semi-Árido, Mossoró-RN, cesareaj@yahoo.com.br

${ }^{2}$ Graduanda em Eng. Agronomica, Universidade Federal Rural do Semi-Árido. E-mail: lul-ut@hotmail.com

${ }^{3}$ Graduanda em Eng. Agronomica, Universidade Federal Rural do Semi-Árido. E-mail: wilmaceledonio@hotmail.com ${ }^{4}$ Dr. Eng. Agrônomo pós doutorando em Fitotecnia, Universidade Federal Rural do Semi-Árido. E-mail: djdagr@ hotmail.com

${ }^{5}$ Dr. Eng. Agrônomo Prof. Associado II - Fruticultura do curso de Agronomia, Universidade Federal Rural do Semi-Árido. E-mail: vander@ufersa.edu.br

${ }^{6}$ Doutoranda em Engenharia de Processos pela Universidade Federal de Campina Grande. Campina Grande, Paraíba. E-mail: alinecarla.edu@ gmail.com
} 


\section{INTRODUCTION}

Winemaking, although recent in Brazil, has made great progress since the 1980s, with the establishment and adaptation of wineries in search of grapes and wines of better quality. It is currently a promising activity, mainly due to the increasing consumption of grape juices and wines, in addition to in natura consumption (SATO et al., 2009).

The vegetative cycle of the vine in temperate regions extends from budding and leaf fall, while, in tropical regions, the cycle distinguish by the absence of leaf fall or by a period of dormancy per se. The vines show only a reduction in metabolic activities due to the decrease in water availability after harvesting the fruits (SANTOS, 2012).

The vegetative cycle subdivides into several periods: growth period, from budding until the end of growth; reproductive period, from flowering to maturation of fruits; and tissues ripening, from the growth stop to the ripening of branches (GALET, 1983).

The study of phenology helps to find new grape varieties by characterizing the duration of developmental phases in relation to climate, especially seasonal variations, which may be used to interpret how the different climates affect the cultures (TERRA et al., 1998). The knowledge of phenological stages is primordial for studies of extension of harvest period (JUBILEU et al., 2010).

Phenology bases on observations of externally visible stages of development (phenophases), such as bud emergence, leaf development, flowering and fruit development. The organization of phenological dates provides important ecological information about the average duration of different phenophases of species in an area, as well as about the location and differences determined by climates at the beginning of each phase (LARCHER, 2000).

In this work, we aimed to characterize the phenological behavior of five grape varieties (Malbec, Syrah, Cabernet Sauvignon, Merlot Noir, and Chardonnay) in the Martins-RN micro-region.

\section{MATERIAL AND METHODS}

The experiment was carried out between May and September 2015, in the municipality of Martins, located in the western region of Rio Grande do Norte, Brazil $\left(6^{\circ} 4^{\prime} 59^{\prime \prime} \mathrm{S}-\right.$ $\left.37^{\circ} 54^{\prime} 50^{\prime \prime} \mathrm{W}\right)$, at $745 \mathrm{~m}$ of altitude. According to Köppen classification, the climate of the region is Aw, that is, rainy tropical climate, with dry winter and rainy season extending from January to July, with average annual rainfall between 800 and 1,200 mm (SEPLAN, 2013).

Soils in the experimental area are dystrophic Red Latosol (Oxisol) with clay texture (EMBRAPA, 2013), which chemical analysis showed the following characteristics: $\mathrm{pH}$ $\left(\mathrm{H}_{2} \mathrm{O}\right)=4.13 ; \mathrm{N}=0.91 \mathrm{~g} \mathrm{~kg}^{-1} ; \mathrm{P}=4.75 \mathrm{mg} \mathrm{dm}{ }^{-3} ; \mathrm{K}=80.3 \mathrm{mg}$ $\mathrm{dm}^{-3} ; \mathrm{Na}=11.9 \mathrm{mg} \mathrm{dm}^{-3} ; \mathrm{Ca}=0.80 \mathrm{cmolc} \mathrm{dm}^{-3} ; \mathrm{Mg}=0.70$ cmolc dm ${ }^{-3} ; \mathrm{Al}=0.65 \mathrm{cmolc} \mathrm{dm}^{-3} ; \mathrm{H}+\mathrm{Al}=6.11 \mathrm{cmolc} \mathrm{dm}^{-3}$; $\mathrm{SB}=1.76 \mathrm{cmolc} \mathrm{dm}^{-3} ; \mathrm{t}=2.40 \mathrm{cmolc} \mathrm{dm}^{-3} ; \mathrm{CEC}=8.13$ cmolc $\mathrm{dm}^{-3} ; \mathrm{V}=22 \% ; \mathrm{m}=33 \% ; \mathrm{ESP}=1 \%$; and $\mathrm{OM}=13,83$ $\mathrm{g} \mathrm{kg}^{-1}$.
Figure 1. Average air temperature $\left(\mathrm{C}^{\circ}\right)$ and average rainfall $(\mathrm{mm})$ in the studied area during the period of experiment conduction. Martins, Rio Grande do Norte, Brazil.

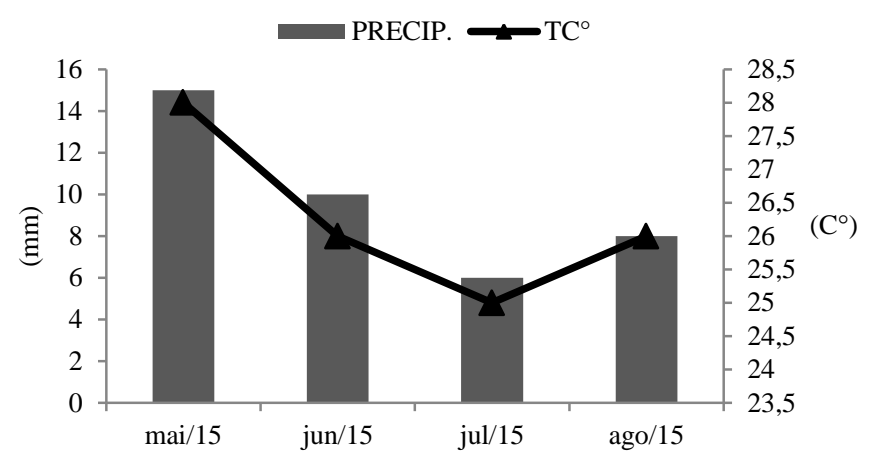

Treatments comprised the following five cultivars of European vines (Vitis vinifera): Malbec, Merlot Noir, Chardonnay, Cabernet Sauvignon, and Syrah.

The vineyard comprised 8-months old plants, cultivated in an "espaldeira" system of conduction, with $3 \times 1.0 \mathrm{~m}$ of spacing, and irrigated by dripping. The experimental design was a randomized block with four replications, and plots consisted of five plants.

We selected five plants to analyze, and pruned them by spur pruning (3-4 buds). After pruning and twisting of branches, we applied manually the $5 \%$ Dormex ${ }^{\circledR}$ sprout inducer with the aid of a brush. Phenological observations were made throughout the cycle, from pruning to harvesting, using the classification proposed by Eichorn and Lorenz (1977).

The following phenological stages were observed: E1 from pruning until the start of budding; E2 - from the beginning of budding until full flowering; E3 - from full flowering to early ripening fruits; and E4 - from early ripening fruits to completely ripened fruits.

The average values of the phenological variables were submitted to analysis of variance (F test) and Tukey's test (5\% probability).

\section{RESULTS AND DISCUSSION}

We show the average values for durations of the phenological periods of the different vine varieties in Table 1.

There was no difference for the pruning-budding period among studied cultivars (seven days for all cultivars). Studying the phenological characteristics of vine production in the São Francisco Valley, Nascimento et al. (2015) showed that the cultivars Syrah, Chenin Blanc and Chardonnay grew faster than other assessed cultivars. Carvalho (2016), studying the phenology and thermal and productive requirements of grapevine cultivars in Lavras, Minas Gerais, verified that the duration between pruning and budding varied from 16 to 20 days among the assessed cultivars.

Budding-flowering period lasted from 21 days for Malbec, Syrah, and Merlot Noir cultivars; and 24 and 26 days for the cultivars Cabernet Sauvignon and Chardonnay, respectively. Hernandes et al. (2010) found higher values for the cultivar Niagara Rosada (34 days), Moscatel de Jundiaí and Seibel 10096 (39 and 41 days, respectively). Carvalho (2016), analyzing the phenology and thermal requirement of grapevine cultivars in Lavras, Minas Gerais, also found higher values than ours for following cultivars: Isabel (31 
days); Bordô (26 days); Niagara and Concord (29 days); Isabel Precoce (30 days); Cora (33 days); Concord clone 30 (32 days); Rubia (31 days); and Violet (30 days).

Syrah and Malbec cultivars had the shortest durations of the flowering-ripening period, with 34 and 35 days respectively (Table 1). The cultivars Cabernet Sauvignon and Merlot Noir had 38 days, and Chardonnay had the longest period, with 39 days from flowering to fruit ripening. Hernandes et al. (2010) observed longer durations in Jundiaí, São Paulo, where Maximo and Seibel 10096 cultivars presented 53 days, and Isabel and Niagara Rosada cultivars showed durations of 65 to 67 days. Jubileu et al. (2010), found values of 42 and 50 days for the cultivar Cabernet
Sauvignon produced out of season in northern Paraná, in the harvests of 2007 and 2008, respectively.

From the ripening until the harvest, the cultivar Cabernet Sauvignon showed the lowest duration (35 days), followed by the cultivars Syrah (36 days), Merlot Noir (37 days), Chardonnay, and Malbec (both with 38 days) (Table 1). Hernandes et al. (2010) found a similar value for the Máximo cultivar (36 days) and a shorter value for Niagara Rosada (22 days). For the cultivars Isabel, Seibel 10096, Madalena, and Moscatel de Jundiaí the values varied between 26 and 30 days. Amaral et al., studying vines in Uruguaiana and Quaraí, Rio Grande do Sul, found the lowest values for Chardonnay (18 days), the same values as ours for Cabernet Sauvignon (35 days), and larger values for Merlot Noir (39 days).

Table 1. Duration, in days, of the different vine cultivars phenological periods. Martins, Rio Grande do Norte, Brazil.

\section{CULTIVAR}

\section{PERIODS}

\begin{tabular}{cccccc}
\hline Pruning-Budding & $7 \mathrm{a}$ & $7 \mathrm{a}$ & $7 \mathrm{a}$ & $7 \mathrm{a}$ & $21 \mathrm{a}$ \\
Budding-Flowering & $21 \mathrm{a}$ & $21 \mathrm{a}$ & $24 \mathrm{~b}$ & $38 \mathrm{~b}$ & $26 \mathrm{c}$ \\
Flowering-Ripening & $35 \mathrm{a}$ & $34 \mathrm{a}$ & $38 \mathrm{~b}$ & $37 \mathrm{a}$ & $39 \mathrm{~b}$ \\
Ripening-Harvest & $38 \mathrm{~b}$ & $36 \mathrm{a}$ & $35 \mathrm{a}$ & $\mathbf{1 0 3 b}$ & $38 \mathrm{~b}$ \\
\hline Pruning-Harvest (Total Cycle) & $\mathbf{1 0 1 a}$ & $\mathbf{9 8 a}$ & $\mathbf{1 0 5 b}$ & $\mathbf{1 1 0 c}$ \\
\hline
\end{tabular}

*Averages followed by the same horizontal letter do not differ from each other at the 5\% level according to the Tukey's test.

The cultivar Syrah showed the shortest duration of total cycle (from pruning to fruit harvest), with 98 days. The cultivars Malbec, Merlot Noir, Cabernet Sauvignon, and Chardonnay had 101, 103, 105 and 110 days respectively (Table 1). Our values were much lower than those reported by Borghesan et al. (2011), of 174 days for Cabernet Sauvignon, Merlot Noir, and Sauvignon Blanc cultivated in São Joaquim, Santa Catarina, and those reported by Jubileu et al. (2010) for Cabernet Sauvignon and Alicante. Sato et al. (2011), studying the cultivars Cabernet Sauvignon and Tannat, both in Paraná, verified a duration of total cycle of 128 and 130 days, respectively. Hernandes et al. (2010), studying American cultivars and hybrids, found cycles ranging from 146 to 149 days. The Isabel cultivar had an average duration of 142 days, and Niagara Rosada showed the shortest cycle, with about 135 days.

\section{CONCLUSIONS}

Syrah cultivar showed the smallest total cycle, with 98 days, followed by the cultivars Malbec, Merlot Noir, Cabernet Sauvignon, and Chardonnay, with 101, 103, 105, and 110 days, respectively.

\section{REFERENCES}

AMARAL, U. DO; MARTINS, C. R.; FILHO, R. C.; BRIXNER, F. G.; BINI, D. A. Caracterização fenológica e produtiva de videiras Vitis vinífera L. cultivadas em Uruguaiana e Quaraí/RS. Revista da FZVA, v.16, p.22-31. 2009.

BORGHESAN, M.; GAVIOLI, O.; PIT, F. A.; SILVA, A. L. Comportamento vegetativo e produtivo da videira e composição da uva em São Joaquim, SC. Pesquisa Agropecuária Brasileira, v. 46, p. 398-405. 2011.
CARVALHO E. Fenologia, exigência térmica e produção de cultivares de videiras (vitis spp.) em Lavras, MG. Tese (Doutorado) - Universidade Federal de Lavras. 2016. $63 \mathrm{f}$.

EICHORN, K. W.; LORENZ, H. Phaenologische Entwicklungstadien der Rebe. Nachrichtenblatt des Deutschen Pflanzenschutzdienstes, Stuttgart, n.29, p.119 120, 1977.

EMBRAPA. Sistema brasileiro de classificação de solos. Rio de Janeiro: Embrapa Solos. 2013. 353.

GALET, P. Précis de viticulture . 4.ed. Montpellier: DÈhan, 1983. 584p.

HERNANDES, J. L.; PEDRO JUNIOR, M. J. P.; SANTOS A. O.; TECCHIO M. A. Fenologia e produção de cultivares americanas e híbridas de uvas para vinho, em Jundiaí-SP. Revista Brasileira de Fruticultura, v. 32, p. 135-142. 2010.

JUBILEU, B. S.; SATO, A. J.; ROBERTO, S. R. Caracterização fenológica e produtiva das videiras 'Cabernet Sauvignon' e 'Alicante' (Vitis vinifera L.) produzidas fora de época, no norte do Paraná. Revista Brasileira de Fruticultura, v. 32, p. 451-462. 2010.

LARCHER, W. Ecofisiologia Vegetal. Tradução de Carlos Henrique Britto de Assis Prado. São Carlos: RiMa Artes e Textos, 2000. 531p.

MANDELLI, F. Comportamento fenológico das principais cultivares de Vitis vinifera L. para a região de Bento Gonçalves, RS. Dissertação (Mestrado em Agrometeorologia) - Escola Superior de Agricultura "Luiz de Queiroz", Universidade de São Paulo, Piracicaba. 1984. 125 f. 
NASCIMENTO, J. H B.; COSTA, J. P. D.; SOUZA E. M. C.; REGO, J. I. S.; LEÃO, P. C. S. Caracterização fenológica de cultivares de uvas para elaboração de vinhos no Vale do São Francisco na safra do primeiro semestre de 2015. In: Simpósio de Fruticultura do Vale do São Francisco, 1., 2015, Juazeiro. Resumos... Petrolina: UNIVASF. 2015.

SANTOS, C. M. G. Fisiologia e metabolismo da videira cv. Syrah no Submédio do Vale do São Francisco sob três estratégias de irrigação. Tese (Doutorado em Produção Vegetal) - Universidade Estadual Paulista "Júlio de Mesquita Filho", Botucatu. 2012. 145 p.

ATO, A. J.; JUBILEU, B. S.; ASSIS, A. M.; ROBERTO, S. R. Fenologia, produção e composição do mosto da 'Cabernet Sauvignon' e 'Tannat' em clima subtropical. Revista Brasileira de Fruticultura, 33, 491-499. 2011
SATO, A. J.; SILVA, B. J. DA; BERTOLUCCI, R.; CARIELO, M.; GUIRAUD, M. C.; FONSECA, I. C. DE B.; ROBERTO, S. R. Evolução da maturação e características físico-químicas de uvas da cultivar Isabel sobre diferentes porta-enxertos na Região Norte do Paraná. Semina: Ciências Agrárias, v.30, n.1, p-11-20, 2009.

SEPLAN, Secretaria de Estado do Planejamento e das Finanças do RN. Perfil do Rio Grande do Norte. Natal: SEPLAN, 2013.191p.

TERRA, M. M.; PIRES, E. J. P.; NOGUEIRA, N. A. M. Tecnologia para produção de uva Itália na região Noroeste do Estado de São Paulo. 2. ed. Campinas: CATI, 1998. 58p. (Documento Técnico, 97). 